\title{
Sanayi 4.0 Geçiş Süreçlerinde Kritik Başarı Faktörlerinin DEMATEL Yöntemi ile Değerlendirilmesi
}

\author{
Evaluation of Critical Success Factors in the Transitional Processes of \\ Industry 4.0 using DEMATEL Method
}

Aydın KOÇAK',

Orcid no: 0000-0003-3023-7271

Aslı DIYADIN ${ }^{2}$

Orcid no:0000-0003-0446-4059

\begin{abstract}
ÖZET
Bilgi sistem ve teknolojilerindeki hızlı büyüme Dünya'yı tek pazar haline getirmesi sonucu işletmeler tedarik zincirini yönetmek konusunda zorlanmaya başlamışlardır. Bu anlamda tedarik zincirinin daha etkin yönetilmesi arayışları sonucunda Sanayi 4.0, son yillarda yayılmaya başlayan bir kavram olmuştur. Bunun sonucu olarak işletmeler 3. Sanayi devriminde 4. Sanayi devrimine geçmeye hazırlanmaktadırlar. Bu geçiş sürecinde işletmelerin başarısını etkileyen faktörlerin belirlenmesi ve bu faktörlerin etkilerinin anlaşılması Sanayi 4.0'a geçiş süreçlerinin etkinliği açısından önemli bir konudur.

Bu çalışmada öncelikle Sanayi 4.0 geçiş süreçlerinde kritik başarı faktörleri belirlenmesi için literatür çalışmasıgerçekleştirilmiştir. Sonrasında bufaktörler İzmir ilinde yer alan, tekstil sektöründe Dünya ölçeğinde üretim yapan ve Sanayi 4.0 süreçlerini başlatmış olan Almanya merkezli bir işletmenin karar vericileri tarafından değerlendirilmiştir. Elde edilen veriler DEMATEL yöntemi kullanılarak işletmenin Sanayi 4.0 geçiş süreçlerini etkileyen başarı faktörleri analiz edilmiştir.
\end{abstract}

Anahtar Kelimeler: Sanayi 4.0, Kritik Başarı Faktörleri, DEMATEL

\section{GiRiş}

Günümüzde ürün hayat seyirlerinin kısalması Ar-Ge, tasarım ve üretim süreçlerinin hızlanarak pazara hızlı cevap verme zorunluluğunu doğurmuştur. Bununla beraber parti büyüklüklerinin oldukça küçülmesi hatta yakın gelecekte bire doğru yaklaşacağının öngörülmesi kişiye özel üretimi ön plana çıkartarak başta üretim olmak üzere işletmenin tüm süreçlerinde esnek sistemlerin kullanılmasını zorlamaktadır. Tüm bu değişimler verimlilik, esneklik, kalite gibi rekabet silahlarının yapısını yeniden tanımlayarak değer ya-

\begin{abstract}
Enterprises have difficulty in managing their supply chain as the World has become a single market because of rapid growth in information systems and technologies. In this sense, Industry 4.0 has become popular in recent years as a result of seeking ways to manage supply chain more effectively. Consequently, enterprises are getting prepared to move from the 3rd Industrial Revolution to the 4th Industrial Revolution. Identification of the factors affecting the success of enterprises in this transition process and understanding the effects of these factors are important in terms of the effectiveness of the process of transition to Industry 4.0.

In this study, firstly literature review was carried out to determine critical success factors in the processes of transition to Industry 4.0. Then, these factors were evaluated by decision makers of a German company which is located in Izmir, is a global producer in the textile sector and has initiated the Industry 4.0 processes. All data was evaluated using the DEMATEL method in order to analyze the success factors affecting the enterprise's process of transition to the industry 4.0.
\end{abstract}

Keywords: Industry 4.0, Critical Success Factors, DEMATEL

ratma zincirinin dijitalleşmesinde yeni modellerin arayışını beraberinde getirmiştir.

Yüksek teknoloji destekli üretim sistemleri ile sınırIı kaynakların daha verimli kullanılarak sürdürülebilir üretimi olanaklı kılması ve ülkelerin ekonomisinin gelişimini sağlaması beklenen Sanayi 4.0, bu arayışların sonucunda ortaya çıkan ve işletmenin değer zincirinin dijitalleşmesine odaklanan bir kavramdır. Özellikle son beş yılda hem uygulamada hem de akademide yaygınlaşan bu kavram yüksek teknoloji, bilgi birikimi, kalifiye iş gücü gerektiren ve işletmelerin çalışma 
kültüründe köklü değişimler yaratacak bir yapıdır. Bu nedenle Sanayi 4.0 süreçlerine geçecek olan işletmelerin Sanayi 4.0'ın bileşenlerini ve önceliklerini doğru tanımlayarak buna göre stratejilerini belirlemesi geçiş süreçlerindeki başarısını doğrudan etkileyecektir. Sanayi 4.0 henüz yeni olgunlaşan bir konu olmasından dolayı hem uygulamada hem de literatürde Sanayi 4.0'ın başarı faktörleri üzerinde mutabık kalınmış bir yapı bulunmamaktadır. Bu çerçevede yapılan çalışmada literatürdeki bu boşluğu doldurmak amacıyla Sanayi 4.0 geçiş süreçlerindeki kritik başarı faktörleri araştırılmıştır. Araştırma sonucu oluşturulan dokuz faktör DEMATEL yöntemi ile değerlendirilmiştir.

Bu çalışma, Sanayi 4.0 ile ilgili yapılmış akademik çalışmaların azlığı açısından bir boşluğu doldurmakla birlikte, kullandığı yöntem açısından da farklılık göstermektedir. Ayrıca bu çalışma ile Sanayi 4.0'a geçecek olan işletmeler için de bir yol haritasının oluşturulması amaçlanmıştır.

Yapılan bu çalışmanın ikinci bölümünde Sanayi 4.0 kavramı bir süreç olarak ele alınarak temel yapısı açıklanmıştır. Literatür çalışmasının yer aldığı üçüncü bölümde Sanayi 4.0 ile ilgili yapılan çalışmalar incelenmiştir. Dördüncü bölümde ise Sanayi 4.0 uygulama süreçlerindeki kritik başarı faktörlerine yer verilmiştir. Beşinci bölümünde ise çalışmanın yöntemi olan DEMATEL yöntemi ayrıntılandırılmaktadır. Çalışmanın uygulama bölümü olan altıncı bölümde ise belirlenen kritik başarı faktörleri uygulamanın yapıldığı işletmenin karar vericileri tarafından değerlendirilmiştir. Sonrasında değerlendirme sonuçlarına DEMATEL yöntemi uygulanmış ve başarı faktörlerinin etki ilişki haritası oluşturulmuştur. Son bölümde ise tüm sonuçlar değerlendirilmiştir.

\section{BIR SÜREÇ OLARAK SANAYI 4.0}

Sanayi 4.0, gelecek için planlanarak günümüzde temelleri atılmaya başlanmış olan "4. Sanayi Devrimi" olarak adlandırılan bir gelişim sürecidir. Sanayi devrimleri ile Dünya'da üretim alanında önemli bir yol kat edilerek kitlesel üretime geçilmiş, üretim tesisleri kurulmuş ve makineleşmeye gidilmiştir. Günümüze kadar sanayi alanı gelişimini sürdürerek enformasyon ve iletişim teknolojilerindeki yenilikleri de yanına alarak bilgi toplumuna uygun bir hale bürünmüştür. Şekil 1'de ayrıntılı olarak açıklanan sanayi devrimlerinin kilometre taşları zaman periyodu içerisinde buhar teknolojisinin, elektrik teknolojisinin, elektronik ve enformasyon teknolojilerinin ve siber fiziksel sistemlerin üretimde kullanımı olarak karşımıza çıkmaktadır.

Şekil 1: Sanayi Devriminin Gelişimi

\section{Sanayi Devrimi \\ İmalat otomasyonunu ileri safhalara taşımayı başaran elektronik ve bilgi teknolojilerinin devreye girişi Illk programlanabilir mantıksal denetleyici (PLC), Madicon 084 1969}

\section{Sanayi Devrimi Siber- fiziksel sistemlere dayalı üretim Günümüz ve gelecek}

2. Sanayi Devrimi İşbölümüne dayalı, elektrik enerjili kitlesel üretimin devreye girişi İlk üretim hattı, Cincinnati Mezbahaları 1870

\section{Sanayi Devrimi} Su ve buhar enerjisine dayalı mekanik üretim tesislerinin devreye girişi İlk mekanik dokuma tezgahı 1784

Kaynak: Kagermann, H.,Wahlster, W. ve Helbig, J. (2013) "Recomendations for Implementing the Strategic Initiative Industrie 4.0", Acatech Raporu. 
Şekil 1'de görüldüğü üzere 18. yy sonunda, su ve buhar gücünün ilk kez dokuma tezgâhlarında kullanılmasıyla Birinci Sanayi Devrimi başlamıştır. İkinci Sanayi Devrimi, elektrik teknolojisi ve kimyasal teknikler sayesinde ortaya çıkarak kısa sürede Avrupa, Amerika Birleşik Devletleri ve Japonya'da yayılmıştır. Ford'un kullandığı üretim bandı tekniği ile kitlesel üretimi gerçekleştirmek mümkün hale gelerek verimlilikte artış sağlanmıştır. Üçüncü Sanayi Devriminde ise elektronik ve enformasyon teknolojilerinin kullanıldığı otomasyona dayalı imalat yapıları devreye girmiştir. Ardından teknoloji kullanımının en üst seviyeye çıktığı ve internet ve enformasyon teknolojilerinin birleştiği siber-fiziksel sistemlerden oluşan Sanayi 4.0'a ulaşılmıştır.

Sanayi 4.0, ilk olarak 2011 yılında Hannover Ticaret fuarında Almanya'nın 2020 Yüksek Teknolojisi Stratejisi Hareket Planının (High-Tech Strategy 2020 Action Plan) bir parçası olarak Kagermann tarafından tanıtılmıştır. Sanayi 4.0, siber fiziksel sistemlerin, nesnelerin ve hizmetlerin internetinin ve akıllı fabrikaların bütünleşerek ürünlerin, iş ortaklarının ve işletme çevresinin bütünsel bir çerçevede iletişimini sağlayan dijital bir değer zincirinin yaratılarak imalatın otomasyona dayalı olarak dijitalleşmesi şeklinde tanımlanabilir (Kagermann, Wahlster ve Helbig, 2013, Oesterreich ve Teuteberg, 2016).

Alman Bilim ve Mühendislik Ulusal Akademisi'nin yayınladığı Sanayi 4.0 raporunda, Sanayi 4.0 ile müşterinin özel istek ve ihtiyaçlarının karşılanabileceği, daha esnek üretim sistemlerinin oluşturulabileceği, karar verme süreçlerinin optimize edilebileceği, kaynakların verimli ve etkin kullanılabileceği, yeni hizmetler aracılığıyla yeni değer yaratacak fırsatların mümkün olabileceği, örgütteki demografik değişikliklere hızlı cevap verilebileceği ve çalışanların iş ve özel hayat arasındaki dengeyi daha kolay sağlayabileceği belirtilmiştir (Kagermann, Wahlster ve Helbig, 2013).

Sanayi 4.0'ın temel yapısı siber fiziksel sistemler ile nesnelerin ve hizmetlerin internetinin bütünleştiği akılı fabrikalar üzerine kurulmaktadır.

Sanayi 4.0; internet tabanlı, büyük verileri işleyebilen ve transfer edebilen siber fiziksel sistemlerden meydana gelmektedir (Schlechtendahl vd., 2014). Siber fiziksel sistemler, yeni çalışma modelleri ile insan etkileşimli olarak fiziksel ve teknolojik kabiliyetleri bütünleştiren yeni nesil sistemler olarak ifade edilebilir (Baheti ve Gill, 2011). Siber fiziksel sistemler, dijital bir ağ yapısı oluşturmak için üretim tesislerini, depoları ve lojistik süreçleri bütünleştiren sistemlerdir (Wang vd., 2016a).

Broy, Kagermann ve Achatz (2010), işletmenin süreçlerine, araçlara, makinelere ve üretim hatlarına gömülü olan siber fiziksel sistemlerin özelliklerini şu şekilde belirtmişlerdir:

- Sensör ve işleticiler (actuators) kullanılarak doğrudan veri toplanır

- Kablolu, kablosuz, local ya da global olarak dijital ağlarla bütünleşiktir

- Veri ve hizmetler global olarak kullanılır

- Çoklu insan- makine arayüzü bulunan sistemlerdir

Lee, Bagheri ve Kao (2015), siber fiziksel sistemleri 5 aşamadan oluşan bir piramitte tanımlamışlardır. Piramidin en alt aşaması akıllı iletişim seviyesi olarak belirtilmektedir. İkinci seviye, akıllı analizlerin yapılarak çoklu boyutta veri ilişkisinin sağlandığı ve verinin enformasyona dönüştüğü seviyedir. Birbirleriyle ilişkisi olan makinalar arasında enformasyon ağlarının oluşturulduğu üçüncü aşama siber aşamasıdır. Bu aşama, verilerin sınıflandırılarak makineler arası veri akışının sağlandığı ve verilerin analiz edildiği aşamadır. Sistemin kapsamlı enformasyon üreterek, kullanıcıların bu enformasyonu karar verme aşamasında kullandığı seviye bilişsellik seviyesidir. Bilişsellik seviyesinde enformasyon, bir takım rapor ve görsel araçlarla uzman kullanıcılara ulaştırılır. Piramidin zirvesi ise, makinaları kendi kendini yapılandırdığı, geri bildirim ve denetimin olduğu yapılandırma aşamasıdır.

Sanayi 4.0'ın birbiri ile bütünleşik ağ yapısını sağlayan diğer önemli bir unsur ise nesnelerin ve hizmetlerin interneti kavramıdır. Önceleri nesnelerin interneti olarak ortaya çıkan bu kavram nesnelerin ve hizmetlerin interneti olarak güncellenerek daha anlamlı bir yapıya kavuşmuştur.

Nesnelerin interneti; internet tabanlı ağlar ve arayüzler aracılığıyla sistemlerin, araçların ve hizmetlerin arasındaki iletişimi sağlayarak fiziksel dünya ve bilgisayar temelli sistemlerin bütünleştirilmesidir (De Cremer, Nguyen, ve Simkin, 2016). Nesnelerin interneti sadece üretimdeki makine ve araç gereçlerle ilgili değil, aynı zamanda hizmetlerle de ilgilidir. Nesnelerin ve hizmetlerin interneti bilgi, nesne, hizmet ve insanlar arasında bağlantı kurmayı mümkün kılmaktadır. Böylelikle, Sanayi 4.0 yapısı içerisinde 
siber fiziksel sistemler aracılığıyla üretim, pazarlama, lojistik ve hizmete kadar uçtan uca entegre akıllı sistemler meydana gelmektedir (Kagermann, Wahlster ve Helbig, 2013).

Bir ürünün değer zinciri göz önüne alındığında, Sanayi 4.0 yapısı içerisinde hammaddenin tedarikinden başlanarak ürünün tüketici tarafından tüketildiği ve yeniden ürüne ihtiyaç duyduğu ana kadar zincirin tüm halkaları nesnelerin ve hizmetlerin interneti ile birbirlerine bağlı olması mümkün olmaktadır. Bu durumda, üretim sürecinde bir hammadde eksilirse sistem bu hammadde bitmeden, tedarik süreci ya da tüketicinin satın aldığı ürün tüketildiğinde bitmeden satın alma süreci tekrar başlayabilecektir. Bu teknoloji ile tüm süreç bir zincir şeklinde ilerlemek yerine, eksikliğin sürekli yenilendiği bir halka şeklinde ilerleyecektir. Bunun sonucu olarak üretimde verimlilik sağlanmasının yanısıra hizmet kalitesi de artacaktır.

Nesnelerin ve hizmetlerin interneti ile siber fiziksel sistemlerin entegrasyonu yanında akıllı ürünler üreten akıllı fabrikalar Sanayi 4.0'ın diğer önemli yapı taşlarından birisidir (Hermann, Pentek ve Otto, 2016). Akıllı fabrikalar, siber fiziksel sistemlerin sanal ve gerçek dünyayı birleştirmesiyle iş ve teknik süreçlerin bir araya gelmesi olarak tanımlanabilir (MacDougall,
2014). Akıllı fabrika, kendi kendini yönetebilen sistemlerle donatılmış her yerde bilişim (Ubiquitous Computing) teknolojileri, akıllı teknolojileri ve akıllı ürünleri içeren dijital sistemlerdir (Lasi vd., 2014).

Küçük, esnek, merkezileşmemiş ve kendi kendini kontrol edebilen akıllı fabrikalarda üretilen akıllı ürünler, değişen tüketici ihtiyaçlarına göre hızlı bir şekilde tasarlanarak üretilebilmektedir (Erol, Schumacher ve Sihn, 2016). Akıllı fabrikaların bu şekildeki esnek ve modüler olma özellikleri, hem ürünlerin kişiselleştirmesini hem de küçük parti büyüklüklerinin verimli ve karlı bir şekilde üretilmesini olanaklı kılmaktadır (Wang vd., 2016a). Bununla beraber dijital ve akıllı ağlarla üretim kaynaklarının yönetimi ve kullanımı daha etkin bir şekilde gerçekleştiğinden dolayı Sanayi 4.0 sürdürülebilir üretim için önemli fırsatlar sunmaktadır (Stock ve Seliger, 2016).

Sanayi 4.0 yapısı içerisinde fabrikalar bugünkü fabrikalardan farklı olarak kendi kendini yönetebilen, otomasyona dayalı ve müşteri beklentilerine göre esnekliğin çok üst boyutlara ulaştığı fabrikalar olarak tasarlanmaktadır. Tablo 1'de Sanayi 4.0'ın akıllı fabrika özellikleri ile geleneksel fabrikanın özellikleri karşılaştırılmaktadır.

Tablo 1: Akıllı Fabrika ile Geleneksel Fabrika Kıyaslaması

\begin{tabular}{|l|l|}
\hline Akıllı Fabrikada Üretim Sistemi & Geleneksel Fabrikada Üretim Sistemi \\
\hline $\begin{array}{l}\text { Kaynak Çeşitliliği: Çok çeşitli ürünü küçük parti } \\
\text { büyüklüğünde üretebilmek için farklı tiplerde kaynak } \\
\text { sistemde yer almaktadır }\end{array}$ & $\begin{array}{l}\text { Sınırlı ve Önceden Belirlenmiş Kaynaklar: Özel bir } \\
\text { ürünü kitlesel olarak üretebilmek için kaynak israfını en } \\
\text { aza indirgemek amacıyla gerekli kaynaklar dikkatle ve özel } \\
\text { olarak planlanır }\end{array}$ \\
\hline $\begin{array}{l}\text { Dinamik Rotalama: Bir üründen diğer bir ürüne geçer- } \\
\text { ken, ihtiyaç duyulan kaynaklar ve rotalar otomatik ve anlık } \\
\text { olarak yeniden düzenlenir }\end{array}$ & $\begin{array}{l}\text { Sabit Rotalama: İnsan gücü ile değiştirilmediği sürece } \\
\text { ürim hattı sabittir. }\end{array}$ \\
\hline $\begin{array}{l}\text { Geniş ve Kapsamlı Ağ Yapısı: Innsanlar, makinalar, ürünler } \\
\text { ve enformasyon sistemleri yüksek hızda işlem gören ağ } \\
\text { yapılarıyla birbirlerine bağlanır ve etkileşim kurarlar. }\end{array}$ & $\begin{array}{l}\text { Atölye Bazında Kontrol Ağı: Makineler arası iletişim ge- } \\
\text { rekli değildir ve istasyon bazında kontrol mevcuttur. }\end{array}$ \\
\hline $\begin{array}{l}\text { Derin Birleşme: Akıllı fabrika, endüstriyel kablosuz ağ, } \\
\text { bulut, nesnelerin ve hizmetlerin interneti ve enformasyon } \\
\text { teknolojilerinin olduğu bütünleşik bir yapıda işler. }\end{array}$ & $\begin{array}{l}\text { Ayrılmış Tabaka: Üretimdeki araç ve gereçler enformas- } \\
\text { yon sisteminden ayrı çalışır. }\end{array}$ \\
\hline $\begin{array}{l}\text { Kendi Kendine Örgütlenme: Kontrol işlevi birden fazla } \\
\text { öğe tarafından gerçekleştirilir. Akıllı öğeler, sistem dina- } \\
\text { mikleri ile baş edebilmek için birbirleri ile iletişim kurarlar. }\end{array}$ & $\begin{array}{l}\text { Bağımsız Kontrol: Her araç önceden programlanmış } \\
\text { görevleri yerine getirir. Bir araçtaki problem, tüm sistemi } \\
\text { etkiler. }\end{array}$ \\
\hline $\begin{array}{l}\text { Büyük Veri: Akıllı̈öğeler büyük veri üretir, bu veriler geniş } \\
\text { bantlara sahip ağlarla aktarılır ve bulut bu büyük veriyi } \\
\text { işler. }\end{array}$ & $\begin{array}{l}\text { Tekil Enformasyon: Bir makine kendi süreç enformasyo- } \\
\text { nunu üretir ve kaydeder. Ancak bu enformasyon nadiren } \\
\text { başka makineler tarafından kullanılır. }\end{array}$ \\
\hline
\end{tabular}

Kaynak: Wang, S., Wan, J., Li, D., ve Zhang, C. (2016a) "Implementing Smart Factory of Industrie 4.0: an Outlook", International Journal of Distributed Sensor Networks, 1-10. 


\section{LITERATÜR ÇALIŞMASI}

Sanayi 4.0 kavramı temel olarak uygulamaya yönelik ve son beş yılda ilgi gören bir konu olmasından dolayı literatürde akademik çalışmaların azlığı göze çarpmaktadır. Konu ile ilgili olarak çeşitli kurumların yayınladığı raporlar ile beraber, akademik olmayan çeşitli dergilerde kısa makaleler ve az sayıda akademik çalışma bulunmaktadır. Oesterreich ve Teuteberg (2016) ve Herman, Pentek ve Otto (2016) Sanayi 4.0 ile ilgili olarak yaptıkları literatür çalışmalarında bu konudaki akademik çalışmaların yetersizliğini vurgulamışlardır.

Acatech, Deloitte, GTAI, BIBB, IAB, Boston Consulting Group, PricewaterhouseCoopers ve TUSIAD gibi çeşitli kurumların hazırladığı konu ile ilgili raporlarda temel olarak Sanayi 4.0 kavramı ve unsurları, Sanayi 4.0 ile ilgili beklentiler ve ulusal ya da küresel bağlamda etkilerinden bahsedilmiştir (Broy, Kagermann ve Achatz, 2010, Kagermann, Wahlster ve Helbig, 2013, Deloitte, 2014, MacDougall, 2014, Wolter vd., 2015, Rübmann vd., 2015, Tansan vd., 2016).
Bu çerçevede akademik literatürde Sanayi 4.0'ın kritik başarı faktörleri ile ilgili akademik bir çalışmaya rastlanmamıştır. Bu nedenle konu ile ilgili çeşitli raporlar, akademik olan ve olmayan makalelerden ve çeşitli olgunluk modellerinden literatür çalışması yapılarak Sanayi 4.0'ın kritik başarı faktörleri belirlenmiştir.

Hem uygulamada hem de akademide Sanayi 4.0 ile ilgili çeşitli olgunluk modelleri bulunmaktadır. Lichtblau vd. (2015), oluşturdukları Industrie 4.0 Readiness modelinde işletmelerin Sanayi 4.0'a hazırlık durumlarını altı boyutta incelemişlerdir. Geissbauer, Vedso ve Schrauf, 2016 yılında yaptıkları araştırma sonucunda sunduğu Industry 4.0/Digital Operations Self Assessment raporunda Sanayi 4.0 geçiş süreçlerinde dijital bir yol haritasını açıklamıştır. Schumacher, Erol ve Sihn (2016), dokuz boyuttan oluşan bir Sanayi 4.0 olgunluk modeli geliştirmişlerdir. Rockwell Automation, 2016 yılında sundukları The Connected Enterprise Maturity Model adındaki olgunluk modelinde beş aşamalı bir Sanayi 4.0 geçiş süreci önermektedirler.

Sanayi 4.0 ile ilgili yapılmış olan akademik çalışmalar ise Tablo 2'de sunulmaktadır.

Tablo 2: Literatür Çalışması

\begin{tabular}{|c|c|c|c|}
\hline YAZAR & YÖNTEM & YIL & KATKI \\
\hline $\begin{array}{l}\text { Thuy Duong Oesterreich } \\
\text { Frank Teuteberg }\end{array}$ & $\begin{array}{l}\text { Sistematik literatür çalışması, } \\
\text { içerik analizi, PESTEL yöntemi ve } \\
\text { örnek olay }\end{array}$ & 2016 & $\begin{array}{l}\text { Dört adet araştırma sorusu oluşturularak inşaat } \\
\text { endüstrisinde Sanayi } 4.0 \text { süreçleri ve durumu } \\
\text { değerlendirilmiştir. }\end{array}$ \\
\hline $\begin{array}{l}\text { Jay Lee } \\
\text { Behrad Bagheri } \\
\text { Hung-An Kao }\end{array}$ & Zaman makinesi yaklaşımı & 2015 & $\begin{array}{l}\text { Sanayi } 4.0 \text { bağlamında, siber fiziksel sistemlerin } \\
\text { temel yapısı } 5 \text { aşamalı bir model ile incelenmiştir. }\end{array}$ \\
\hline $\begin{array}{l}\text { Jan Schlechtendah } \\
\text { Matthias Keinert } \\
\text { Felix Kretschmer } \\
\text { Armin Lechler } \\
\text { Alexander Verl }\end{array}$ & Kavramsal & 2014 & $\begin{array}{l}\text { Sanayi 4.0'a geçişin işletmelerin varolan süreçlerine } \\
\text { adaptasyonu ile ilgili holistik yaklaşım sunulmuştur. }\end{array}$ \\
\hline Paul Wright & Kavramsal & 2014 & $\begin{array}{l}\text { Siber fiziksel sistemlerin üretim alanındaki işlevi ve } \\
\text { etkileri incelenmiştir. }\end{array}$ \\
\hline $\begin{array}{l}\text { Shiyong Wang } \\
\text { Jiafu Wan, } \\
\text { Di Li } \\
\text { Chunhua Zhang }\end{array}$ & Kavramsal & 2016 & $\begin{array}{l}\text { Sanayi } 4.0 \text { geçiş süreçleri için akıllı fabrika } \\
\text { uygulamalarına yönelik bir çerçeve ortaya konarak } \\
\text { teknik gereklilikler ve faydalar değerlendirilmiştir. }\end{array}$ \\
\hline $\begin{array}{l}\text { Shiyong Wang } \\
\text { Jiafu Wan } \\
\text { Daqiang Zhang } \\
\text { Di Li } \\
\text { Chunhua Zhang }\end{array}$ & Kavramsal ve simülasyon & 2016 & $\begin{array}{l}\text { Akıllı fabrikaların teknik işleyiş̧i ile ilgili bir yapı } \\
\text { oluşturularak bu yapı, geliştirilen simülasyon } \\
\text { yazılımı ile değerlendirilmiştir. }\end{array}$ \\
\hline $\begin{array}{l}\text { Pleter J. Mosterman } \\
\text { Justyna Zander }\end{array}$ & $\begin{array}{l}\text { Endüstriyel uygulama, } \\
\text { modelleme ve simülasyon }\end{array}$ & 2016 & $\begin{array}{l}\text { Sanayi } 4.0 \text { yapısı çerçevesinde siber fiziksel sistemler } \\
\text { üzerine bir yapı geliştirilerek çeşitli endüstriyel } \\
\text { uygulamalar ile değerlendirilmiştir. }\end{array}$ \\
\hline $\begin{array}{l}\text { T. Stock } \\
\text { G. Seliger }\end{array}$ & Kavramsal & 2016 & $\begin{array}{l}\text { Sanayi 4.0'ın sürdürülebilir üretim için getireceği } \\
\text { fırsatlar ve var olan durum değerlendirilmiştir. }\end{array}$ \\
\hline Sinan Alçın & Kavramsal & 2016 & $\begin{array}{l}\text { Sanayi } 4.0 \text { 'ın temel özellikleri ve endüstrilere etkileri } \\
\text { incelenmiştir. }\end{array}$ \\
\hline Lutz Sommer & $\begin{array}{l}\text { Sistematik literatür çalışması ve } \\
\text { içerik analizi }\end{array}$ & 2015 & $\begin{array}{l}\text { Küçük ve orta boy işletmelerin Sanayi } 4.0 \\
\text { farkındalığı araştırılmıştır. }\end{array}$ \\
\hline
\end{tabular}




\section{SANAYI 4.0 KRITIK BAŞARI FAKTÖRLERI}

Sanayi 4.0 süreçlerindeki başarı faktörleri konusunda literatür eksikliğinden dolayı aşağıda açıklanan faktörler oluşturulurken literatürde yapılmış çalışmalar, yayınlanmış raporlar ve çeşitli kurumların oluşturduğu olgunluk modelleri dikkate alınmıştır.

\section{Stratejik vizyon}

Sanayi 4.0, teknoloji tabanlı olarak üretim kabiliyetlerinin iyileştirilmesinden öte işletme süreçlerinde paramadigmal bir değişim getirmektedir (Erol, Schumacher ve Sihn, 2016). Bu nedenle Sanayi 4.0 bir teknoloji yatırımı olarak değil, tüm işletmeyi kapsayan ve yeni iş modelleri getiren uzun dönemli bir işletme stratejisi olarak görülmelidir. Bu anlamda işletme stratejileri ile bütünleşik bir Sanayi 4.0 vizyonu ve stratejisi oluşturularak uygulanmalıdır. Bu strateji kapsamında Sanayi 4.0'a geçiş sürecinde kısa, orta ve uzun dönemi kapsayan dijital bir yol haritası oluşturulmalıdır. Bununla beraber oluşturulan strateji ve yol haritasının performans kriterlerinin belirlenerek izlenmesi diğer bir önemli konudur.

Oluşturulacak stratejik yol haritasının üç temel niteliği bulunmalıdır (Erol, Schumacher ve Sihn, 2016):

- Teknoloji destekli olarak yeni dönüşüm için sürekli bir planlama ve analiz alt yapısını sağlamak,

- Sanayi 4.0 ile ilgili vizyon, strateji ve projelerin bütünsel bir yapıda işleyişini sağlamak,

- Sanayi 4.0 geçiş sürecindeki tüm faaliyetlerin izlenmesi ve yönetimi için rehber niteliğinde olmak.

\section{Örgütsel yapı}

Sanayi 4.0, işletmeler açısından bir teknoloji yatırımı olarak değil kültürel değişim yaratan bir işletme stratejisi olarak görülmelidir. Bu nedenle işletmenin örgütsel ve kültürel yapısı Sanayi 4.0'ın önemini işletme içerisinde yerleştirmek ve kabullendirmek için organize edilmelidir. Örneğin örgütsel yapı içerisinde Sanayi 4.0 ile ilgili birim ve pozisyonlar oluşturulmalıdır. Ayrıca çalışanlar için yenilikçiliği ortaya çıkaracak takım çalışmasını destekleyen ve serbest bir çalışma ortamı da gerekmektedir (Lichtblau vd., 2015). Geissbauer, Vedso ve Schrauf'ın 2016 yılında Sanayi 4.0 üzerine yaptığı araştırmada dijital kültür ve eğitim eksikliği Sanayi 4.0 geçiş süreçlerde işletmeleri karşılaştığı en önemli eksiklik olarak belirtilmiştir.
Sanayi 4.0 yenilik odaklı süreç ve teknolojilerin kullanıldığı bir yapıya sahip olmalıdır. Bu anlamda Sanayi 4.0'a geçiş ve sonrasında sürdürülebilir bir uygulama için işletmenin örgütsel yapısı içerisinde araştırma geliştirme, yenilik ve teknoloji yönetimi ve bilgi yönetimi gibi alanlara da yatırım yapması gereklidir.

\section{Değer Zincirinde Yatay Entegrasyon}

Müşteri tatmini yaratabilmek, esnek ve hızlı bir yapı oluşturabilmek için ürünlerin hayat seyrindeki tüm değer zincirinin ortak bir yapıda yönetimi önemli bir noktadır. Sanayi 4.0'ın etkin işleyişi açısında Sanayi 4.0 geçiş sürecinde, işletme içinde yer alan alt sistemler ile beraber müşteri istek ve intiyaçları doğrultusunda tedarikçiler gibi değer zincirinde yer alan her bir halkanın da siber fiziksel sistemler yardımıyla entegrasyonunun sağlanması gerekmektedir (Oesterreich ve Teuteberg, 2016). Bu anlamda Sanayi 4.0 geçiş süreçlerinde işletmenin iç süreçleri ile dış süreçleri ortak bir platformda bir araya gelmelidir. Yatay entegrasyon, işletmenin gelen ve giden lojistik, üretim ve pazarlama gibi iç süreçleri ile tedarikçiler gibi değer zincirindeki diğer işletmeler ve müşteriler arasında enformasyon, malzeme ve enerji akışııın sağlanması için çeşitli enformasyon teknolojilerinin bütünleştirilmesidir (Kagermann, Wahlster ve Helbig, 2013). Siber fiziksel sistemler de yatay entegrasyon içerisinde hem tedarikçi hem de müşteri tarafında dijital bir yapı sağlamaktadır. Yatay entegrasyonun temel amacı, değer zinciri içerisinde mal ve enformasyon akışının optimize edilmesidir (Wolter vd., 2015).

\section{Dikey Entegrasyon}

Sanayi 4.0 süreçlerinde pazara hızlı cevap vermenin temel koşullarından biri işletme süreçlerinin dijital bir yapıda gerçekleşmesidir. Bu anlamda işletme içinde bulunan tüm alt sistemler birbiriyle iletişime geçebilecek şekilde entegre edilmelidir. Bu sebeple Sanayi 4.0 geçiş süreçlerinde üretimden dağıtıma, tüm süreçlerde karşılıklı işbirliği sağlayabilen sanal ve fiziksel yapılar gerekmektedir (Erol, Schumacher ve Sihn, 2016). Dikey entegrasyon, işletmenin iç süreçleri ile ilgili olup işletme içerisinde malzeme, ürün ve veri akışının optimize edilmesi için satış, mühendislik, üretim planlama ve kontrol ve işletmenin diğer planlama seviyeleri gibi farklı hiyerarşik seviyelerin çeşitli enformasyon teknolojileri ile bütünleştirilmesi olarak ifade edilebilir (Kagermann, Wahlster ve Helbig, 2013, Wolter vd., 2015). Dikey entegrasyon süreçlerinde si- 
ber fiziksel sistemler ile akıllı süreçler ve akıllı ürünler birbirine bağlanarak kendi kendini yönetebilen akıllı imalat yapısı oluşturulur.

\section{Enformasyon sistem ve teknolojileri alt yapısı}

Sanayi 4.0, fiziksel dünya ile sanal dünyayı bütünleştiren bir yapıya sahiptir. Bu yapının etkin işleyebilmesi için gelişmiş teknolojilerin kullanılması kaçınılmazdır. Öncelikle iç süreçlerin yönetilmesinde kurumsal kaynak planlaması alt yapısının kullanıcı ve süreç intiyaçlarını eksiksiz bir şekilde karşılayacak şekilde yürütülüyor olması gerekmektedir. Buna ek olarak Sanayi 4.0'ın etkin işleyişi için sanal gerçeklik sağlayan simülasyon, otomasyon ve tüm süreçlerde entegrasyon sağlayacak yazılımlar gibi teknolojiler de kullanılmalıdır. Bununla beraber işletmede RFID, sensor, mobil, bulut ve robot teknolojilerinin, büyük veri yönetimini sağlayacak teknolojilerin ve başta makineler arası iletişimi sağlayacak teknolojiler olmak üzere tüm değer zinciri içerisindeki birimler arasındaki iletişimi sağlayacak teknolojilerin kullanımı için gerekli alt yapısı bulunmalıdır.

\section{Akıllı fabrikalar}

Önceki bölümlerde de ayrıntılı olarak belirtildiği gibi akıllı fabrikalar Sanayi 4.0'ın temel yapılarından birisidir. Akıllı fabrikalar içerisinde, gerçek zamanlı verinin kullanıldığı, internet tabanlı olarak gelişmiş enformasyon ve iletişim teknolojileri içeren ve kendi kendini yöneten sistemlere sahip akıllı ürün ve makineler bulunmaktadır. Akıllı fabrikalar içerisinde makineler arasındaki iletişimin sağlanmasıyla makinelerin süreç içerisindeki diğer sistemler ile bütünleşmesi önemlidir. Ayrıca akıllı fabrikalarda dijital ve bütünsel bir alt yapıda üretim kontrol sistemleri, kurumsal kaynak planlaması, ürün hayat yönetimi, ürün veri yönetimi, makine veri toplama, bilgisayar destekli tasarım gibi sistemler de kullanılmalıdır.

\section{Büyük veri yönetimi}

Sanayi 4.0, işletmenin değer zincirini dijital bir alt yapıyla bütünleştirdiğinden dolayı süreçte oluşan verinin toplanması mümkün olmaktadır. Fakat oluşan bu büyük verinin tüm süreçlerdeki karar ve yönetim faaliyetlerinde ve yeni iş modellerinde etkin ve gerçek zamanlı bir şekilde kullanımının yönetimi Sanayi 4.0 süreçleri için hayati bir öneme sahiptir. Sanayi 4.0'ın temel bileşeni olan akıllı fabrikaların işleyebilmesi için akıllı nesneler, büyük veri analizi ile bütünleştirilmelidir (Wang vd., 2016b). Nesnelerin ve hizmetlerin interneti, büyük veri ve bulut bilişim uygulamalarının bütünsel kullanımı Sanayi 4.0 süreçlerinde karar vermeyi iyileştirmektedir. Ayrıca başta üretim olmak üzere tüm değer zincirinde oluşan büyük verinin yönetimini sağlayan enformasyon sistem ve teknolojilerinin işletme içinde bulunması ve veri güvenliği de diğer önemli konulardır. Güvenlik ve depolama alt yapısı büyük veri yönetimindeki temel sıkıntılar arasında yer almaktadır. Sanayi 4.0 süreçlerinde bulut teknolojisinin kullanımı, yüksek alt yapı yatırım ihtiyacına gerek kalmadan güvenli bir şekilde büyük verinin yönetimini mümkün kılmaktadır.

\section{Nitelikli işgücü yapısı}

Sanayi 4.0 uygulamaları yenilik odaklı, sürekli eğitim ve gelişim tabanlı işgücü stratejisi ile teknolojinin bütünleştiği bir sosyo-teknik yaklaşım gerektirmektedir (Kagermann, Wahlster ve Helbig, 2013). Sanayi 4.0 beraberinde işletmelere yeni iş modelleri getirmesiyle operasyonel süreçlerin insansız olarak gerçekleşmesinden dolayı fiziksel güce dayalı işgücü azalarak, beyinsel güce dayalı işgücü ihtiyacının artacağı beklenmektedir. Bu nedenle Sanayi 4.0'a geçiş süreçlerinde işletmeler, dijital değişime ayak uyduracak ve gerçekleştirecek nitelikli işgücüne ihtiyaç duyacaklardır. Bu anlamda Sanayi 4.0'a geçiş yapacak işletmeler yeniliğe açık, sorgulayan, analitik, dijital süreçlere yatkın, işbirlikçi, bilgi tabanlı çalışan kısaca bilgi iş̧̧isi olarak tanımlanabilecek işgücü istihdamı yapmalıdır. Ayrıca işletmelerde enformasyon teknolojileri, otomasyon teknolojileri, büyük veri analitiği ve güvenliği ve işbirlikçi yazılımlar alanlarında da istihdam intiyacı ortaya çıkacaktır (Lichtblau vd., 2015).

\section{Güvenlik}

Sanayi 4.0 içerisinde dijital ekosistem ancak veri gizliliği, veri ve iletişim güvenliği ve entellektüel varlığın korunması ile hayatını sürdürebilir (Geissbauer, Vedso ve Schrauf, 2016). Internet tabanlı ve yüksek teknoloji içeren bir sistem olması Sanayi 4.0 süreçlerini siber saldırılara açık hale getirmektedir. Deloitte, 2014 yılında yayınladığı raporda Sanayi 4.0'ın veri hırsızlığı, hacker saldırılar ve sanayi casusluğu gibi risklere açık olduğunu belirtmiştir. Raporda gerçekleştirilen ankete katılan işletmelerin \% 48'ı siber riski çok önemli ve \%36'sı ise önemli derecede değerlendirmiştir. Sanayi 4.0 bütünleşik bir yapı içerisinde olmasından dolayı tüm sistemi içerecek bir güvenlik stratejisi, yapısı ve standartlarının oluşturulması gerekmektedir (Kagermann, Wahlster ve Helbig, 2013). Bu güvenlik yapısı içerisinde iç süreçlerdeki verinin ve veri akışının, dış süreçlerdeki veri akışının ve bulut hizmetindeki 
verinin güvenliği ile ilgili çözümler uygulanmalıdır (Lichtblau vd., 2015).

\section{5. ÇALIŞMA YÖNTEMI}

Önceki bölümde ayrıntılı olarak açıklanan başarı faktörlerinin değerlendirilmesinde DEMATEL (The Decision Making Trial and Evaluation Laboratory Method) yöntemi kullanılmıştır. DEMATEL yöntemi; başlangıçta çelişkili ve karmaşık problemlerin anlaşılır hale gelmesi için kullanılmış olsa da ilerleyen dönemlerde yaygın olarak, karmaşık nedensel yapıları görselleştirmek, faktörler arasındaki etkileşim ve faktörlerin değerlendirilmesi için kullanılmıştır (Zhou vd., 2011). DEMATEL, bir sistemin bileşenleri arasındaki doğrudan ve dolaylı ilişkileri çeşitlerine ve önem derecesine göre analiz etmede kullanılabilecek en etkili yöntemlerden biridir (Li vd., 2014). Ayrıca DEMATEL, karmaşık yapılar arasındaki ilişkiler için yapısal bir model oluşturan ve analiz eden bir yöntemdir (Wu, 2008).

Literatür incelendiğinde, Sanayi 4.0 başarı faktörlerinin DEMATEL yöntemi ile değerlendirildiği bir çalışmaya rastlanmamasına karşın çeşitli alanlardaki başarı faktörlerinin bu yöntem ile değerlendirildiği görülmektedir. Wu ve Chang (2015), yeşil tedarik zinciri yönetimindeki kritik faktörlerini belirlemede DEMATEL yöntemini kullanmışlardır. Acil durum yönetimindeki kritik başarı faktörlerinin belirlenmesinde Zhou, Huang ve Zhang (2011) bulanık DEMATEL, Li vd. (2014) ise DEMATEL yönteminden yararlanmışlardır. Shieh, Wu ve Huang (2010), hastane hizmet kalitesinin başarı faktörlerinin belirlenmesinde DEMATEL yöntemini kullanmışlardır. Bai ve Sarkis (2013), Gri Iliş̧kisel Analizle bütünleşik bir biçimde DEMATEL yöntemini kullanarak süreç yönetiminde kritik başarı faktörlerini değerlendirmişlerdir. Wu (2012), bilgi yönetimi uygulamalarındaki kritik başarı faktörlerinin sınıflandırılmasında Bulanık DEMATEL yönteminden yararlanmıştır. Patil ve Kant (2014), tedarik zincirinde bilgi yönetimi uygulamalarındaki kritik başarı faktörlerini belirlerken Bulanık DEMATEL yöntemini kullanmışlardır. Kabak vd. (2015), Bulanık DEMATEL yöntemini kullanarak Türkiye'deki demir çelik sektörünün kritik başarı faktörlerini belirlemişlerdir. Yin vd. (2012), araştırma geliştirme projelerinin kritik başarı faktörlerinin belirlenmesinde DEMATEL, Yapısal Yorumlayıcı Modelleme ve Analitik Ağ Süreci yöntemlerinin bütünleştiği bir metodoloji uygulamışlardır. Gandhi vd. (2016), yaptıkları çalışmada Hindistan imalat endüstrisinde yeşil tedarik zinciri yönetimi uygulamalarındaki başarı faktörlerini değerlendirmek için Analitik Hiyerarşi ve DEMATEL Yöntemlerinin bütünleştirildiği bir yaklaşım önermişlerdir. Nilashi vd. (2015), inşaat projelerindeki kritik başarı faktörlerinin değerlendirilmesinde Analitik Ağ Süreci ve DEMATEL yöntemlerinin bütünleştirildiği bir model önermişlerdir.

DEMATEL yönteminin temel aşamaları ve çalışmanın metodolojisi aşağıda gösterilmektedir. (Wu, 2008, Nilashi vd., 2015):

\section{1. aşama: Direkt iliş̧i matrisinin oluşturulması}

Bu aşamada, uzmanların faktörleri ikili değerlendirmesi için bir ölçek belirlenir. Direk ilişki matrisinin kurulmasına yarayacak bu ölçek çeşitlilik göstermekle beraber, bu çalışmada aşağıda dilsel ifadelerle beraber gösterilen beş aşamalı ikili değerlendirme ölçeği kullanılmıştır.

Tablo 4: DEMATEL Metodu Değerlendirme Ölçeği

\begin{tabular}{|c|c|}
\hline Sayısal Değer & Tanım \\
\hline 0 & Etkisiz \\
\hline 1 & Düşük Etki \\
\hline 2 & Orta Etki \\
\hline 3 & Yüksek Etki \\
\hline 4 & Çok Yüksek Etki \\
\hline
\end{tabular}

Kaynak: Nilashi, M., Zakaria, R., Ibrahim, O., Majid, M., Zin, R., ve Farahmand, M. (2015) "MCPCM: A DEMATEL-ANP-Based MultiCriteria Decision-Making Approach to Evaluate the Critical Success Factors in Construction Projects", Arabian Journal for Science \& Engineering, 40(2): 343-361.

Direkt ilişki matrisi, nxn yapıya sahip olup uzmanIarın Tablo 4'deki ölçeği kullanarak faktörlerin birbirini etkileme düzeylerini ikili olarak değerlendirmesinden sonra oluşmaktadır.

\section{Aşama: Normalize edilmiş direkt ilişki matrisinin oluşturulması}

Bu aşamada bütünleşik karar yapısının bozulmasının en aza indirilmesi için normalleştirme yapılır. Burada direk ilişki matrisi (A) kullanılarak normalize edilmiş direkt ilişki matrisi $(X)$ aşağıdaki formüller kullanılarak oluşturulur. Burada direkt ilişki matrisinin her bir değeri, bu matrisin satır toplamlarının maksimum değerine bölünerek normalize edilir.

$$
\begin{aligned}
& X=k . A \\
& k=\frac{1}{\frac{\max }{1 \leq i \leq n} \sum_{j=1}^{n} a i j}, \quad i, j=1,2,3 \ldots \ldots . n
\end{aligned}
$$




\section{Aşama: Toplam ilişki matrisinin oluşturulması}

Bu aşamada, normalize edilmiş ilişki matrisi $(X)$ elde edildikten sonra aşağıdaki formül kullanılarak toplam ilişki matrisi $(\mathrm{T})$ oluşturulur. I birim matrisi ifade etmektedir.

$$
T=X .(I-X)^{-1}
$$

\section{Aşama: $D$ ve $R$ değerlerinin belirlenmesi}

$\mathrm{Bu}$ aşamada toplam ilişki matrisinden yararlanılarak aşağıdaki formüller aracılığıyla faktörlerin etkileme gücünü ifade eden $d_{i}$ ve etkilenme seviyesini ifade eden $r_{j}$ değerleri hesaplanır. Toplam ilişki matrisinin satır değerlerinin toplamı D değerini, sütun değerlerinin toplamı ise $R$ değerini ifade etmektedir.

$$
\begin{aligned}
& T=\left[t_{i j}\right]_{n x n}, i, j=\ldots \ldots \ldots \ldots . . n \\
& D=\left[\sum_{j=1}^{n} t_{i j}\right]_{n x 1}=\left[t_{i}\right]_{n \times 1} \\
& R=\left[\sum_{j=1}^{n} t_{i j}\right]_{1 x n}=\left[t_{i}\right]_{n x 1}
\end{aligned}
$$

\section{Aşama: $D+R$, $D-R$ ve faktör ağırlıklarının belirlenmesi ve etki grafiğinin oluşturulması}

Bu aşamada her bir faktör için ilişki düzeyini belirten $D+R$ ve faktörlerin etkileme seviyelerini belirleyen $D-R$ değerleri hesaplanır. Etki grafiğinde yatay eksende yer alan $D+R$ değeri bir faktörün etkileşim düzeyini ifade etmektedir. Başka bir deyişle bir faktörün $D+R$ değeri yükseldikçe bu faktörün diğer faktörler ile etkileşiminin yüksek olduğunu göstermektedir. Etki grafiğinin dikey ekseninde ise bir faktörün etki gücünü gösteren $D-R$ değerleri yer almaktadır. Eğer bir faktörün D-R değeri pozitif ise etkileyen grubunda yer aldığı, negatif ise etkilenen grubunda yer aldığı anlamına gelmektedir.
Ayrıca faktörlerin problem açısından önem ağırlıkları aşağıdaki formüller ile hesaplanır.

$$
\begin{aligned}
& W_{i}=\left\{\left(D_{i}+R_{i}\right)^{2}+\left(D_{i}-R_{i}\right)^{2}\right\}^{1 / 2} \\
& W_{i}=\frac{w_{1}}{\sum_{i=1}^{n} w_{i}}
\end{aligned}
$$

\section{Aşama: Etki ilişki haritanın oluşturulması}

Bu aşamada faktörlerin birbirleri arasındaki ilişkinin yönünü ve gücünü ortaya koymak için toplam ilişki matrisinin tüm değerlerinin ortalaması kullanılarak bir eşik değer hesaplanıp etki ilişki haritası oluşturulur. Etki ilişki haritası faktörlerin birbirleri ile olan etki düzeyi ve yönünü anlamakta görsel bir araç sağlamaktadır.

\section{UYGULAMA}

Bu çalışmanın uygulaması İzmir ilinde yer alan, Sanayi 4.0 geçiş süreçlerini gerçekleştiren ve Dünya ölçeğinde üretim yapan bir tekstil işletmesinde gerçekleştirilmiştir. Firmada Sanayi 4.0 geçiş süreçleri için özel olarak bir birim kurulmuş olup bu birimin karar vericileri belirlenen dokuz başarı faktörünü değerlendirmiş ve sonuçlar DEMATEL yöntemi ile analiz edilmiştir. Uygulama bölümü aşağıda gösterildiği gibi bir önceki bölümde ayrıntılı olarak açıklanan aşamalar ile gerçekleştirilmiştir.

\section{1. aşama: Direkt ilişki matrisinin oluşturulması}

Bu aşamada işletmenin Sanayi 4.0 biriminde yer alan ve geçiş süreçlerinde karar verici pozisyonunda olan dört uzman görüşü alınmıştır. Uzmanlar başarı faktörlerini ayrı ayrı değerlendirmek yerine beraber beyin fırtınası yaparak değerlendirmeyi tercih

\begin{tabular}{|c|c|c|c|c|c|c|c|c|c|}
\hline & F1 & F2 & F3 & F4 & F5 & F6 & F7 & F8 & F9 \\
\hline F1 & 0 & 3 & 3 & 2 & 0 & 1 & 1 & 0 & 0 \\
\hline F2 & 4 & 0 & 2 & 2 & 1 & 1 & 1 & 0 & 0 \\
\hline F3 & 3 & 3 & 0 & 0 & 1 & 1 & 1 & 0 & 0 \\
\hline F4 & 3 & 4 & 2 & 0 & 2 & 0 & 1 & 2 & 0 \\
\hline F5 & 4 & 2 & 1 & 2 & 0 & 4 & 4 & 4 & 4 \\
\hline F6 & 4 & 3 & 1 & 2 & 3 & 0 & 4 & 4 & 4 \\
\hline F7 & 3 & 1 & 3 & 2 & 4 & 4 & 0 & 4 & 4 \\
\hline F8 & 2 & 2 & 3 & 2 & 2 & 3 & 3 & 0 & 1 \\
\hline F9 & 2 & 2 & 1 & 1 & 4 & 4 & 4 & 3 & 0 \\
\hline
\end{tabular}
etmişlerdir. Sonuç olarak Tablo 4'de yer alan ölçek kullanılarak dilsel ifadeler ile alınan değerlendirme sonuçları sayısal ölçeğe çevrilerek Tablo 5'de gösterilen direkt ilişki matrisi elde edilmiştir.

Tablo 5: Direkt İlişki Matrisi

Stratejik vizyon (F1), Örgütsel Yapı (F2), Değer Zincirinde Yatay Entegrasyon (F3), Dikey Entegrasyon (F4), Enformasyon Sistem ve Teknolojileri Alt Yapısı (F5), Akıllı Fabrikalar (F6), Büyük Veri Yönetimi (F7), Nitelikli İş Gücü Yapısı (F8), Güvenlik ( F9). 


\section{Aşama: Normalize edilmiş direk ilişki matrisinin oluşturulması}

Bu aşamada elde edilen direkt ilişki matrisi 1 ve 2 numaralı formüller kullanılarak Tablo 6'daki normalize edilmiş direkt ilişki matrisi oluşturulmuştur.

Tablo 6: Normalize Edilmiş Direk İlişki Matrisi

\begin{tabular}{|l|c|c|c|c|c|c|c|c|c|}
\hline & F1 & F2 & F3 & F4 & F5 & F6 & F7 & F8 & F9 \\
\hline F1 & 0 & 0,12 & 0,12 & 0,08 & 0 & 0,04 & 0,04 & 0 & 0 \\
\hline F2 & 0,16 & 0 & 0,08 & 0,08 & 0,04 & 0,04 & 0,04 & 0 & 0 \\
\hline F3 & 0,12 & 0,12 & 0 & 0 & 0,04 & 0,04 & 0,04 & 0 & 0 \\
\hline F4 & 0,12 & 0,16 & 0,08 & 0 & 0,08 & 0 & 0,04 & 0,08 & 0 \\
\hline F5 & 0,16 & 0,08 & 0,04 & 0,08 & 0 & 0,16 & 0,16 & 0,16 & 0,16 \\
\hline F6 & 0,16 & 0,12 & 0,04 & 0,08 & 0,12 & 0 & 0,16 & 0,16 & 0,16 \\
\hline F7 & 0,12 & 0,04 & 0,12 & 0,08 & 0,16 & 0,16 & 0 & 0,16 & 0,16 \\
\hline F8 & 0,08 & 0,08 & 0,12 & 0,08 & 0,08 & 0,12 & 0,12 & 0 & 0,04 \\
\hline F9 & 0,08 & 0,08 & 0,04 & 0,04 & 0,16 & 0,16 & 0,16 & 0,12 & 0 \\
\hline
\end{tabular}

Stratejik vizyon (F1), Örgütsel Yapı (F2), Değer Zincirinde Yatay Entegrasyon (F3), Dikey Entegrasyon (F4), Enformasyon Sistem ve Teknolojileri Alt Yapısı (F5), Akıllı Fabrikalar (F6), Büyük Veri Yönetimi (F7), Nitelikli İ̧̧ Gücü Yapısı (F8), Güvenlik ( F9).

\section{Aşama: Toplam ilişki matrisinin oluşturulması}

Elde edilen normalize edilmiş direkt ilişki matrisi 3 numaralı formül kullanılarak Tablo 7'deki toplam ilişki matrisi elde edilir.

Tablo 7: Toplam İlişki Matrisi

\begin{tabular}{|l|c|c|c|c|c|c|c|c|c|}
\hline & F1 & F2 & F3 & F4 & F5 & F6 & F7 & F8 & F9 \\
\hline F2 & 0,1230 & 0,2109 & 0,1920 & 0,1363 & 0,0697 & 0,1048 & 0,1095 & 0,0621 & 0,0479 \\
\hline F3 & 0,22804 & 0,1173 & 0,1708 & 0,1490 & 0,1135 & 0,1197 & 0,1248 & 0,0764 & 0,0603 \\
\hline F4 & 0,2849 & 0,2038 & 0,0813 & 0,0682 & 0,1025 & 0,1117 & 0,1141 & 0,0646 & 0,0551 \\
\hline F5 & 0,5110 & 0,3720 & 0,2958 & 0,2862 & 0,2586 & 0,4229 & 0,4328 & 0,4037 & 0,3544 \\
\hline F6 & 0,5030 & 0,3977 & 0,2915 & 0,2815 & 0,3570 & 0,2745 & 0,4222 & 0,3924 & 0,3443 \\
\hline F7 & 0,4783 & 0,3402 & 0,3578 & 0,2811 & 0,3973 & 0,4229 & 0,2946 & 0,4034 & 0,3545 \\
\hline F8 & 0,3375 & 0,2854 & 0,2868 & 0,2188 & 0,2469 & 0,2941 & 0,3017 & 0,1741 & 0,1818 \\
\hline F9 & 0,4121 & 0,3377 & 0,2658 & 0,2315 & 0,3773 & 0,4016 & 0,4095 & 0,3532 & 0,2042 \\
\hline
\end{tabular}

Stratejik vizyon (F1), Örgütsel Yapı (F2), Değer Zincirinde Yatay Entegrasyon (F3), Dikey Entegrasyon (F4), Enformasyon Sistem ve Teknolojileri Alt Yapısı (F5), Akıllı Fabrikalar (F6), Büyük Veri Yönetimi (F7), Nitelikli İ̧̧ Gücü Yapısı (F8), Güvenlik ( F9).

\section{Așama: $D$ ve $R$ değerlerinin belirlenmesi}

Toplam ilişki matrisinde yer alan satır (D) ve sütün (R ) toplamları formül 4, 5 ve 6 kullanılarak oluşturularak Tablo 8'de gösterilmiştir.

\section{Așama: D+R, D-R ve faktör ağırlıklarının belirlenmesi ve etki grafiğinin oluşturulması}

Bu aşamada $D+R$ ve $D-R$ değerleri ve faktörlerin önem dereceleri 7. ve 8. formül kullanılarak hesaplanmış ve Tablo 8'de gösterilmiştir. 
Tablo 8: $D, R, D+R$, D-R Değerleri ve Faktörlerin Önem Dereceleri

\begin{tabular}{|l|c|c|c|c|c|c|}
\hline & D & R & D+R & D-R & w & W \\
\hline F1 & 1,0569 & 3,1587 & 4,2156 & $-2,1018$ & 4,71047287 & 0,11 \\
\hline F2 & 1,2128 & 2,5521 & 3,7649 & $-1,3394$ & 3,996047905 & 0,10 \\
\hline F3 & 1,0297 & 2,1400 & 3,1697 & $-1,1104$ & 3,358569349 & 0,08 \\
\hline F4 & 1,5497 & 1,7498 & 3,2995 & $-0,2001$ & 3,30551675 & 0,08 \\
\hline F5 & 3,3378 & 2,0943 & 5,4321 & 1,2434 & 5,572572595 & 0,13 \\
\hline F6 & 3,2645 & 2,2676 & 5,5320 & 0,9969 & 5,621151794 & 0,14 \\
\hline F7 & 3,3305 & 2,3624 & 5,6929 & 0,9681 & 5,774620178 & 0,14 \\
\hline F8 & 2,3272 & 2,0974 & 4,4247 & 0,2298 & 4,430654417 & 0,11 \\
\hline F9 & 2,9932 & 1,6798 & 4,6730 & 1,3135 & 4,854113346 & 0,12 \\
\hline
\end{tabular}

Stratejik vizyon (F1), Örgütsel Yapı (F2), Değer Zincirinde Yatay Entegrasyon (F3), Dikey Entegrasyon (F4), Enformasyon Sistem ve Teknolojileri Alt Yapısı (F5), Akıllı Fabrikalar (F6), Büyük Veri Yönetimi (F7), Nitelikli İş Gücü Yapısı (F8), Güvenlik ( F9).

Tüm bu verilere göre etki grafiği Şekil 2'de gösterilmektedir.

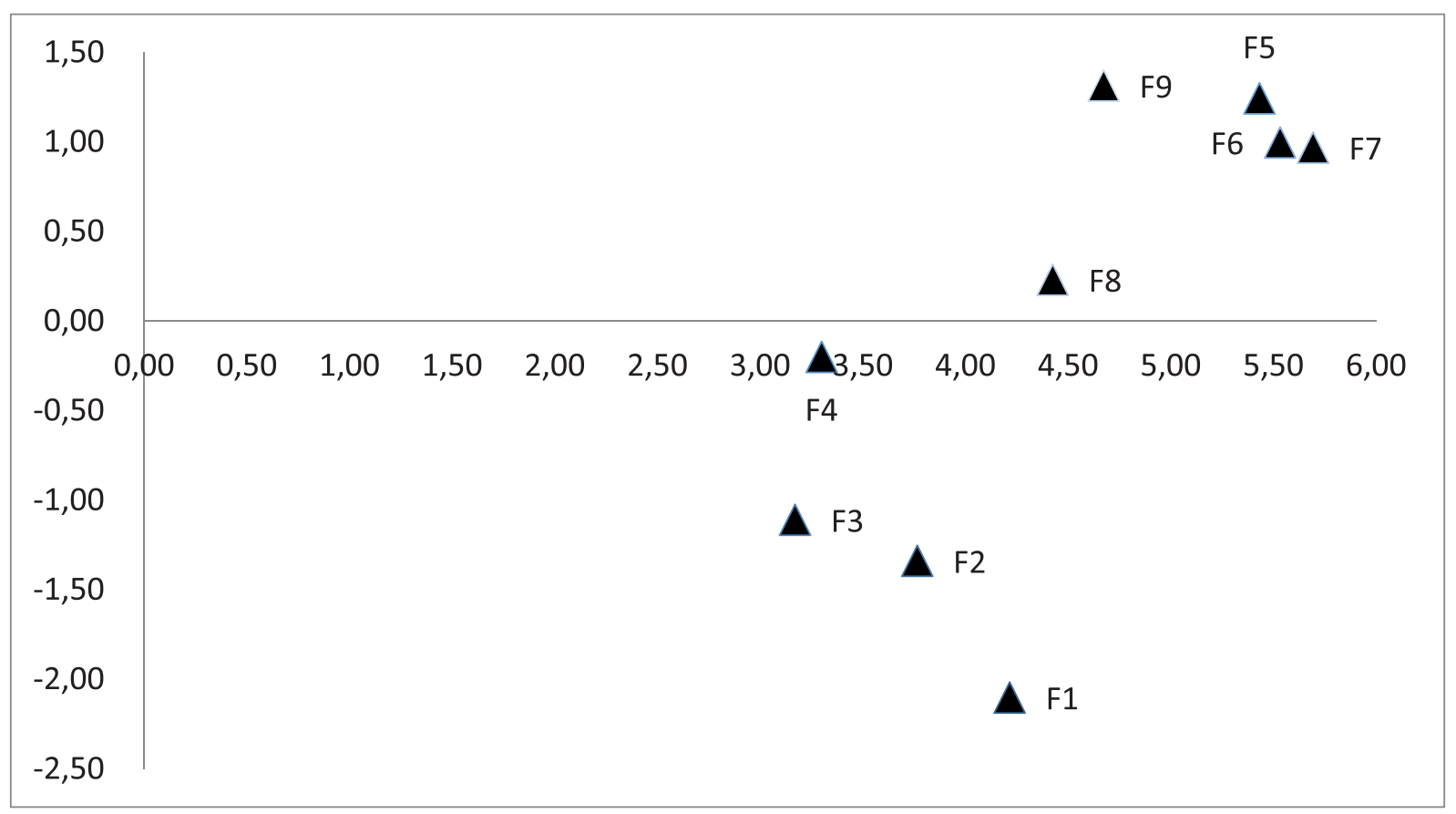

\section{Şekil 2: Etki Grafiği}

\section{Aşama: Etki iliş̧ki Haritanın Oluşturulması}

Etki grafiği faktörlerin etkileyen ve etkilenen olarak gruplara ayırmasına karşın faktörlerin birbirleri ile olan ilişkisinin gücü konusunda bilgi vermemektedir. Bu nedenle etki ilişki haritasını oluşturmak için öncelikle toplam ilişki matrisinin değerlerinin ortalaması olan 0,248175 değeri eşik değer olarak alınmıştır. Bu değerin altındaki ilişkiler göz ardı edilmiştir. Ayrıca toplam etki matrisinin en büyük değeri olan 0,511025 değeri ile eşik değeri arası üç eşit dilime bölünerek ilişki düzeyleri orta, güçlü ve çok güçlü olarak belirlenmiştir. 


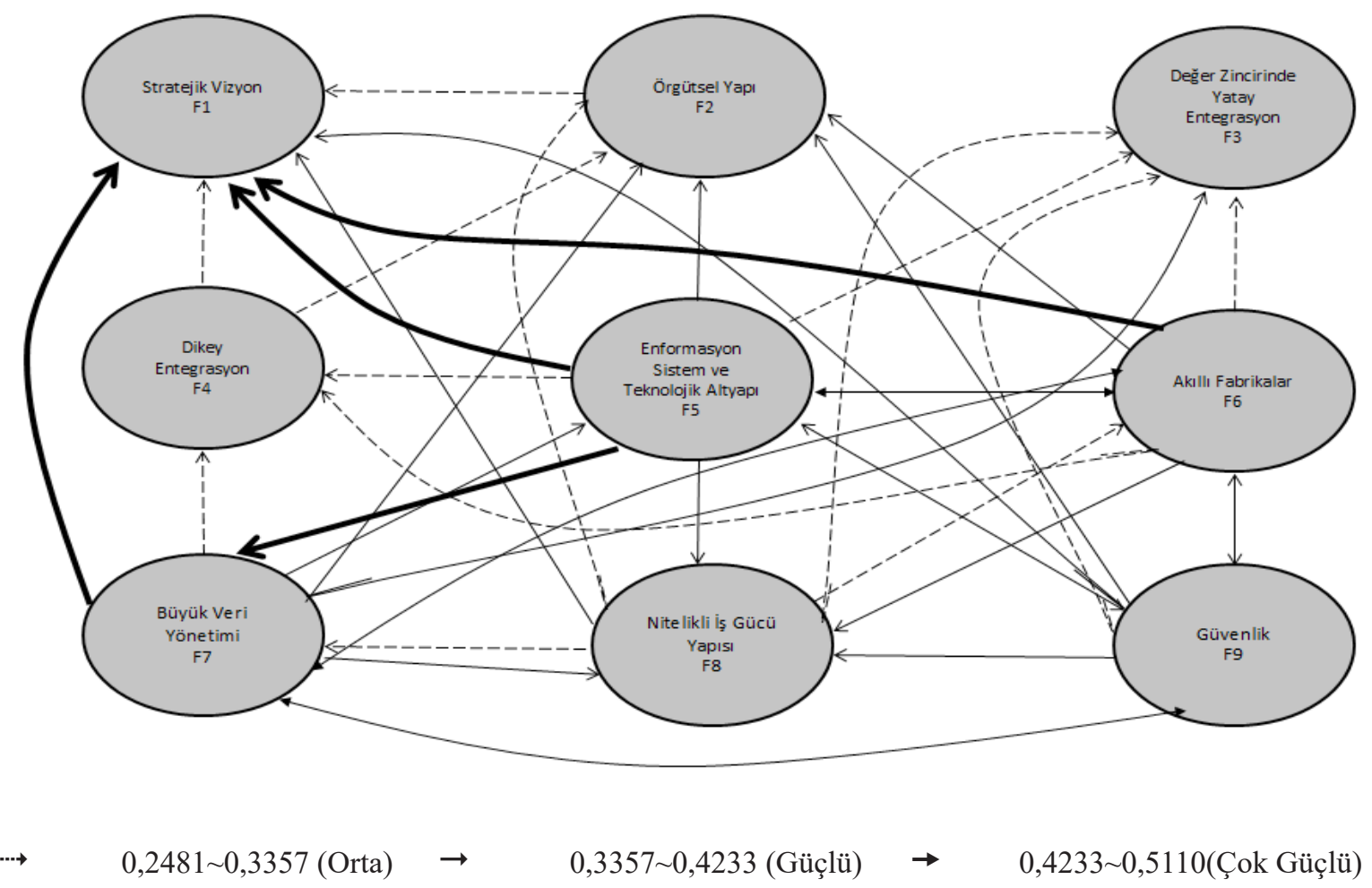

Şekil 3: Etki Illişki Haritası

\section{DEĞERLENDIRME VE SONUÇ}

Yukarıdaki veriler değerlendirildiğinde faktörlerin ilişki düzeylerini belirleyen $D+R$ değerlerine göre ilk üç sırada yer alan sırasıyla büyük veri yönetimi (F7), akıllı fabrikalar (F6) ve enformasyon sistem ve teknolojileri alt yapısı (F5) faktörleri diğer faktörler ile olan ilişkileri yüksek düzeydedir. Bu faktörlerin ilişki düzeylerini etki ilişki haritası vermektedir. Bu faktörler arasındaki en yüksek değere sahip büyük veri yönetimi faktörü Sanayi 4.0 geçiş süreçlerinde en yüksek önceliğe sahip faktördür. Bu faktörün $D-R$ değeri incelendiğinde pozitif başka bir değişle etkileyen grubunda olduğu görülmektedir. Buna karşın $D+R$ değerleri en düşük üç faktör olan örgütsel yapı (F2), değer zincirinde yatay entegrasyon (F3) ve dikey entegrasyon (F4) faktörleri diğer faktörler ile ilişki düzeyleri düşük kalmaktadır.

$D-R$ değerlerine göre ise pozitif değere sahip enformasyon sistem ve teknolojileri alt yapısı (F5), akıllı fabrikalar (F6), büyük veri yönetimi (F7), nitelikli iş gücü yapısı (F8) ve güvenlik (F9) faktörleri etkileyen grubunda yer almaktadır. Bu gruptaki faktörlerin performansı Sanayi 4.0 geçiş süreçlerini bütünsel olarak doğrudan etkilemektedir. Bu nedenle Sanayi 4.0 geçiş süreçlerinde bu faktörlere ilişkin faaliyetler dikkatli olarak gerçekleştirilmeli ve bu faktörlerde yapılacak iyileştirmelerin tüm sistemi etkileyeceği göz önünde bulundurulmalıdır. En büyük pozitif değere sahip güvenlik kriteri en çok etkileyen kriter olarak karşımıza çıkmaktadır. Ayrıca negatif D-R değerine sahip stratejik vizyon (F1), örgütsel yapı (F2), değer zincirinde yatay entegrasyon (F3) ve dikey entegrasyon (F4) faktörleri etkilenen grubunda yer almaktadır.

Bununla beraber faktörlerin önem ağırlıkları incelendiğinde ilk üç sırayı sırasıyla büyük veri yönetimi, akıllı fabrikalar ve enformasyon sistem ve teknolojileri alt yapısı faktörleri yer almaktadır. Bu sonuç Sanayi 4.0 geçiş süreçlerinin başarısında bu üç faktörün işletme açısından en önemli başarı faktörleri olduğunu göstermektedir.

Şekil 2'deki etki grafiği incelendiğinde enformasyon sistem ve teknolojileri alt yapısı (F5) ve güvenlik (F9) faktörleri göze çarpmaktadır. Özellikle bu iki faktör, Sanayi 4.0 geçiş süreçlerinde diğer faktörleri oldukça etkilemektedir. Ayrıca enformasyon sistem ve teknolojileri alt yapısı faktörü önem sırası açısından üçüncü sırada yer almaktadır. Bu faktörün $D+R$ değeri üçüncü iken $D-R$ değeri pozitif ve ikinci sırada yer almaktadır. Güvenlik faktörü ise $D+R$ değeri 
açısından dördüncü sırada yer almasına karşın D-R değeri pozitif ve birinci sırada yer almaktadır. Sonuç olarak öncelikli olarak bu iki faktör, işletmenin Sanayi 4.0 geçiş süreçlerindeki başarısını oldukça etkilemektedir.

Şekil 3'deki etki ilişki haritası incelendiğinde akıllı fabrikalar, enformasyon sistem ve teknolojileri alt yapısı ve büyük veri yönetimi faktörlerinin stratejik vizyon faktörünü çok güçlü derecede etkilediği görülmektedir. Ayrıca enformasyon sistem ve teknolojileri alt yapısı faktörü de büyük veri yönetimi faktörünü de çok güçlü derecede etkilemektedir. Ayrıca enformasyon sistem ve teknolojileri alt yapısı faktörü; örgütsel yapı, akıllı fabrikalar ve nitelikli işgücü yapısı faktörlerini güçlü düzeyde etkilemektedir. Bununla beraber güvenlik faktörü; nitelikli iş gücü yapısı, büyük veri yönetimi, akıllı fabrikalar, büyük veri yönetimi, enformasyon sistem ve tekno- lojileri ve stratejik vizyon faktörlerini güçlü düzeyde etkilemektedir. İşletme Sanayi 4.0 geçiş süreçlerini gerçekleştirirken faktörler arasındaki bu ilişkileri göz önünde bulunması faaliyetlerin etkinliği açısından önem kazanmaktadır.

Yapılan bu çalışmada literatürde henüz yeni yer almaya başlanan Sanayi 4.0 kavramının kritik başarı faktörleri üzerinde çalışılmıştır. Literatürde Sanayi 4.0'ın kritik başarı faktörleri üzerinde mutabık kalınmış bir yapı olmamasından dolayı bu çalışmanın literatürdeki bu boşluğu dolduracağı düşünülmektedir. Ayrıca yapılan çalışmada oluşturulan başarı faktörlerinin uygulamanın yapıldığı işletme açısından değerlendirilmesi DEMATEL yöntemiyle yapılarak faktörlerin etki seviyeleri ve birbirlerini etkileme düzeyleri araştırılmıştır. Bu anlamda yapılan çalışmanın da Sanayi 4.0 geçiş süreçlerini başlatacak olan işletmeler için de bir yol haritası oluşturması amaçlanmıştır.

\section{KAYNAKÇA}

Alçın, S. (2016) "Üretim İçin Yeni Bir İzlek: Sanayi 4.0", Journal of Life Economics, 19-30.

Baheti, R. ve Gill, H. (2011) "Cyber-physical Systems", The Impact of Control Technology, 12: 161-166.

Bai, C., ve Sarkis, J. (2013) "A Grey-based DEMATEL Model for Evaluating Business Process Management Critical Success Factors", International Journal of Production Economics, 146(1): 281-292.

Broy, M., Kagermann, H. ve Achatz, R. (2010) "Agenda Cyber Physıcal" Acatech Raporu.

De Cremer, D., Nguyen, B., ve Simkin, L. (2016) "The Integrity Challenge of the Internet of Things (loT): On Understanding Its Dark Side", Journal of Marketing Management, 1-2: 145-158.

Deloitte, (2014) "4.0-Challenges And Solutions For The Digital Transformation And Use Of Exponential Technologies", White Paper.

Erol, S., Schumacher, A., ve Sihn, W., (2016) "Strategic Guidance Towards Industry 4.0-a Three-Stage Process Model" International Conference on Competitive Manufacturing, 27-29 Ocak, Stellenbosch, Güney Afrika.

Gandhi, S., Mangla, S. K., Kumar, P., ve Kumar, D. (2016) "A Combined Approach Using AHP And DEMATEL for Evaluating Success Factors in Implementation of Green Supply Chain Management in Indian Manufacturing Industries", International Journal of Logistics Research And Applications, 19(6): 537-561.
Geissbauer, R., Vedso, J. ve Schrauf, S. (2016) "Industry 4.0: Building the Digital Enterprise", PricewaterhouseCoopers Raporu.

Hermann, M., Pentek, T., ve Otto, B. (2016) "Design Principles for Industrie 4.0 Scenarios" 49th Hawaii International Conference on System Science, 5-8 Ocak, Koloa, USA.

Kabak, Ö., Ülengin, F., Çekyay, B., Önsel, Ş., ve Özaydın, Ö. (2016) "Critical Success Factors for the Iron And Steel Industry in Turkey: A Fuzzy Dematel Approach", International Journal of Fuzzy Systems, 18(3): 523-536.

Kagermann, H.,Wahlster, W. ve Helbig, J. (2013) "Recomendations for Implementing the Strategic Initiative Industrie 4.0", Acatech Raporu.

Lasi, H., Fettke, P., Kemper, H. G., Feld, T. ve Hoffmann, M. (2014) "Industry 4.0", Business and Information Systems Engineering, 6(4), 239.

Lee, J., Bagheri, B., ve Kao, H. A. (2015) "A CyberPhysical Systems Architecture for Industry 4.0-Based Manufacturing Systems", Manufacturing Letters, 3: 1823.

Li, Y., Hu, Y., Zhang, X., Deng, Y., ve Mahadevan, S. (2014) "An Evidential DEMATEL Method to Identify Critical Success Factors in Emergency Management", Applied Soft Computing, 22: 504-510.

Lichtblau, K., Stich, V., Bertenrath, R., Blum, M., Bleider, M., Millack, A., Schmitt, K., Schmitz, E. ve Schröter, 
M. (2015) "Industrie 4.0 Readiness" VDMA's IMPULSStiftung Raporu.

MacDougall, W., (2014) "Industrie 4.0 - Smart Manufacturing for the Future", Germany Trade and Invest Raporu.

Mosterman, P. J., ve Zander, J. (2016) "Industry 4.0 As A Cyber-Physical System Study", Software and Systems Modeling, 15(1): 17-29.

Nilashi, M., Zakaria, R., Ibrahim, O., Majid, M., Zin, R., ve Farahmand, M. (2015) "MCPCM: A DEMATEL-ANPBased Multi-Criteria Decision-Making Approach to Evaluate the Critical Success Factors in Construction Projects", Arabian Journal for Science and Engineering, 40(2): 343-361.

Oesterreich, T.D., ve Teuteberg, F. (2016) "Understanding the Implications of Digitisation and Automation in The Context of Industry 4.0: A Triangulation Approach and Elements of a Research Agenda for the Construction Industry", Computers in Industry, 83: 121-139.

Patil, S., ve Kant, R. (2014) "Knowledge Management Adoption in Supply Chain: Identifying Critical Success Factors Using Fuzzy DEMATEL Approach", Journal of Modelling in Management, 9(2): 160-178.

Rockwell Automation (2016) "The Connected Enterprise Maturity Model" Rockwell Automation Raporu.

Rübmann, M., Lorenz, M., Gerbert,P., Waldner, M., Justus, J.,Engel, P. ve Harnisch, M. (2015) "Industry 4.0: The Future of Productivity and Growth in Manufacturing Industry", Boston Consulting Group (BCG) Raporu.

Schlechtendahl, J., Keinert, M., Kretschmer, F., Lechler, A., ve Verl, A. (2014) "Making Existing Production Systems Industry 4.0 Ready", Production Engineering, 9(1): 143148.

Schumacher, A., Erol, S. ve Sihn, W. (2016) "A Maturity Model for Assessing Industry 4.0 Readiness and Maturity of Manufacturing Enterprises" Procedia CIRP, 52: 161-166.

Shieh, J. I., Wu, H. H., ve Huang, K. K. (2010) "A DEMATEL Method in Identifying Key Success Factors Of Hospital Service Quality", Knowledge-Based Systems, 23(3): 277 282.

Sommer, L. (2015) "Industrial Revolution-Industry 4.0: Are German Manufacturing SMEs the First Victims of This Revolution?", Journal of Industrial Engineering and Management, 8(5): 1512.
Stock, T., ve Seliger, G. (2016) "Opportunities of Sustainable Manufacturing in Industry 4.0", Procedia CIRP, 40: 536-541.

Tansan, B., Gökbulut, A., Targotay, Ç. ve Eren,T. (2016) "Türkiye'nin Küresel Rekabetçiliği için Bir Gereklilik Olarak Sanayi 4.0 Gelişmekte Olan Ekonomi Perspektifi", TÜSIAD Raporu.

Wang, S., Wan, J., Li, D., ve Zhang, C. (2016a) "Implementing Smart Factory of Industrie 4.0: an Outlook", International Journal of Distributed Sensor Networks, 1-10.

Wang, S., Wan, J., Zhang, D., Li, D., ve Zhang, C. (2016b) "Towards Smart Factory for Industry 4.0: A SelfOrganized Multi-Agent System with Big Data Based Feedback And Coordination", Computer Networks, 101: 158-168.

Wolter, M., I., Mönnig, A., Hummel, M., Schneemann, C., Weber, E., Zika, G., Helmrich, R., Maier, T., Neuber-Pohl, C., (2015) "Industry 4.0 and The Consequences for Labour Market and Economy Scenario", IAB Forschungsbericht Raporu.

Wright, P. (2014) "Cyber-Physical Product Manufacturing", Manufacturing Letters, 2(2): 49-53.

Wu, H. H., ve Chang, S. Y. (2015) "A Case Study of Using DEMATEL Method to Identify Critical Factors in Green Supply Chain Management", Applied Mathematics and Computation, 256: 394-403.

Wu, W. W. (2008) "Choosing Knowledge Management Strategies By Using A Combined ANP and DEMATEL Approach", Expert Systems with Applications, 35(3): 828835.

Wu, W. W. (2012) "Segmenting Critical Factors For Successful Knowledge Management Implementation Using the Fuzzy DEMATEL method", Applied Soft Computing, 12(1): 527-535.

Yin, H.,S., Wang, C.,C., Teng, Y.,L., Hsing, M., Y. (2012) "Application of DEMATEL, ISM, and ANP for Key Success Factor (KSF) Complexity Analysis in R\&D Alliance", Scientific Research and Essays, 7(19): 1872-1890.

Zhou, Q., Huang, W., ve Zhang, Y. (2011) "Identifying Critical Success Factors in Emergency Management Using A Fuzzy DEMATEL method", Safety Science,49(2): 243-252. 